\title{
TAMÁS KRAUSZ
}

\section{LENIN ON GLOBAL HISTORY AND THE GLOBAL HISTORIOGRAPHY ON LENIN ${ }^{1}$}

Lenin's place in the development of the global Marxist history of ideas is frequently misconstrued today, attributing a self-serving, power-grabbing, voluntarist and opportunistic tendency to Lenin's intellectual development and his new findings and innovative analysis of capitalism. Lenin's true legacy must be reclaimed on monopoly capitalism and imperialism, and this paper aims to place them in not only Lenin's real contemporary political and intellectual context, but also traces how his concepts have fared since his passing, up to the early $21^{\text {st }}$ century. The supposed contradiction and dichotomy of a utopian democratic tendency and rigid determinism in Lenin are here altogether removed, and the coherence, realism and historical rootedness of Lenin's thought reclaimed.

On the $100^{\text {th }}$ anniversary of the Great Russian Revolution it is worth remembering Lenin's analysis of global and local history not only because he shaped global history, but because he provided an analytical framework. Lenin's analysis is an important component of the history of the revolution and its intellectual preconditions. Recalling some key elements of this conceptualization of history is worthy of note since they are still relevant today in a broader sense. This study aims at presenting the relationship between Russian and global history in Lenin's analysis and also revealing the elements of his theory that have become a constitutive part of historical thinking.

Keywords: Vladimir Ilyich Ulyanov, imperialism, world-systems approach (world-systems theory), historical views of Lenin, Lenin and the Russian development

Tamás Krausz - D.Sc. in History, Professor Emeritus, Russian Studies Centre, Department of Eastern and Central European History and Historical Russistics, Faculty of Humanities, Eötvös Loránd University (Hungary, Budapest, 1088 Múzeum krt. 6-8.).

E-mail: centre@russianstudies.huＯRCID: https://orcid.org/0000-0003-3717-9887

1 Keynote lecture at the Fifth European Congress on World and Global History (European Congress European Network in Universal and Global History) (ENIUGH), 31 August 2017, Corvinus University, Budapest. 


\section{TODAY'S INTELLECTUAL CLIMATE AND HISTORIOGRAPHY: LENIN'S PERSPECTIVES}

Today's intellectual climate in Eastern Europe is unfavorable for balanced analysis. For instance, mainstream liberal historiography denies or simply ignores the existence of Marxist or critical historiography even in the past, for example in Hungary, which had a strong Marxist school well known also in the West at that time. ${ }^{2}$ Considering that, what is one to say about the ethnonationalist historiography which has become dominant almost everywhere in the region? Also in Hungary, many historians are busy legitimizing the authoritarian neo-Horthyst régime that has been built up in recent years. Still, we shall remember that Marxist-oriented historiography, as Georges Duby underlined at the beginning of the 1980s, was a source of inspiration in France even for non-Marxist historians and thinkers, from Marc Bloch to Lucien Febvre, and so on. ${ }^{3}$

Also we remember that in the 1960s the new current in the historiography of global history, world-systems theory listed Lenin as one of its early intellectual sources, its "ancestor", even though later many of them seemed to have forgotten this inspiration. Today, a historical presentism mixes Lenin's Marxist-based, historically relevant analysis with the legitimacy-providing ideology of state socialism, and in many cases, even Stalinism-and this is often done by scholars who never studied deeply Lenin's historical views. This brutal re-politicization of historiography, which from the 1980s and 1990s, has weighed heavily on history as "the politics of memory", has swept away anything that is Soviet, including first and foremost, Lenin. Recently even Immanuel Wallerstein painted quite a one-sided, "national" picture of Lenin on the occasion of the publication of his book in Moscow. ${ }^{4}$

2 Krausz TAmás, “A magyar történetírás és a marxizmus - Megjegyzések a „kelet-európaiság” problémájához [Hungarian Historiography and Marxism: Comments on the Problem of "East Europeanness"], Eszmélet, no. 94. (Summer 2012) Melléklet [Supplement]. See online: http://www.eszmelet.hu/wp-content/uploads/2018/08/EPA01739_eszmelet_ 2012_94_nyar_182-244.pdf (Accessed June 25, 2019)

3 GEORGE DUbY, GUI LARDREAU, Párbeszéd a történelemről (Budapest: Akadémiai Kiadó, 1993), 108-110. [Original edition: Dialogue about History (Paris: Dialogues, 1980)]

4 Wallerstein referred to Lenin as a Russian "national hero". See online: http://left.by/ archives/939 (Accessed June 15, 2019) 
And still: nobody can deny that Lenin greatly influenced historical thinking and in a narrower sense, historiography in large parts of the world in the $20^{\text {th }}$ century. ${ }^{5}$ Lenin was not a professional historian and some of his statements have been disproved by scientists. Nonetheless, his views, theoretical and methodological convictions have influenced history and have been integrated into historical analyses. But we can rightly underline that Lenin's historical writings, notes and comments had the overt political intention to clarify the historical conditions of the practical roads to the revolution and to show the possibility of a historical change and development, which goes beyond the "capital-system" (István Mészáros). ${ }^{6}$ In line with this intellectual project, Lenin goes back to Marx both in methodology and theory, whom he regarded as his "master teacher"? This means Lenin went beyond the normative and value system, and also the terminology of the capitalist society, and thus, he tried to adapt Marx's scholarship to the conditions of the early $20^{\text {th }}$ century.

Lenin's scholarly analysis set off first and foremost with the theory of social formations in order to understand and interpret global history. On this basis he "re-created" this theory, explicitly concentrating on the history of Russian capitalism and the relationship between Russian capitalism and global historical development. ${ }^{8}$ However, in spite of the

5 В. А. Быстрянский, Ленин - историк. Историзм в ленинизме (Ленинград: Гос. изд-во, 1925) Lenin as a historian was first interpreted in Soviet Russia in 1925 , by party historian Vadim Bystransky. Even though the study complied with the general spirit of those times in the celebration of Lenin. The 35-page-long pamphlet underlines the global spread of the revolutionary movements and the universal historical aspects of the successful revolutions in Lenin's work, namely the perspective and method that he "inherited" from Marx and Engels.

6 How much Lenin needed historical analysis as one condition of the determination of the "right political strategy" is best shown by his comment: On the caricature of Marxism, Vol. 30 , 52. Starting from the specificities of the universal historical development, he argues precisely that the "pure" socialist revolution is impossible. (See the foreword to the volume XIII.)

7 В.Т. Логинов, Владимир Ленин. Выбор пути: Биография (Москва: Республика, 2005), 100., (between the lines) 103.

8 Sее: Б.А. Чагин (под ред.), Социологическая мысль в России. Очерки истории немарксистской социологии последней трети XIX - начала XX века (Ленинград: Наука, 1978), 393-95. In his work published in Russian (vol. 25, 44.) Lenin already observed that the abstention from theory expresses an overall restraint in bourgeois sociology and historical science; they are afraid of the consequences of the laws of historical development in science, which could and would lead to the radical critique of bourgeois social development and the elaboration of a (more) human alternative. See also: Е.Г. Плимак, Политика переходной эпохи. Опыт Ленина (Москва: Весь Мир, 2004). 
rich heritage of critical historiography on this subject ${ }^{9}$, the Lenin-literature seems to have fallen "victim" to the Eastern European regime changes even in the West. The liberal and conservative historiographies have one thing in common, namely, the way they approach Lenin's thinking about historical development: both decompose, disconnect and "deconstruct" Lenin's "legacy", and both neglect-while some historians directly falsifythe original historical and intellectual context of Lenin's objectives, analyses and intellectual heritage. Approached in this way Lenin's views and analyses of history lose their original significance and are presented as a mere rationalization of his direct political goals and interests of power. ${ }^{10}$ The falsification of the actual context pushes Lenin into the narratives of "violence" and "thirst for power" as an "omnipotent leader of the world proletariat." It has become general historical practice to interpret Lenin and his views in terms of very simple antitheses: even so-called "benchmark" works such as recent studies for instance Christopher Read lock Lenin into the double intellectual prison of ultra-democratic, utopian illusions and being an authoritarian-dogmatic Marxist.11 This is a triumph of ideology against history-wiping out a specific "narrative" from contemporary historical discourses.

\section{INSPIRATIONS AND CONCEPTS: RUSSIAN CAPITALISM AS A PART OF GLOBAL CAPITALISM}

In the 1890s Lenin's break with Narodism and Liberalism was a break with the old science, with positivism, politically conformist empiricism and nationalism. Lenin in his "Friends of the People" published in 1894 emphasized in opposition to positivist sociology ${ }^{12}$ that the mere "collection

9 We must stress here that there has been a rich intellectual accumulation in this field: from Perry Anderson to the Hungarian Marxist historical school, from Braudel to Hobsbawm, from Marc Bloch to André Gunder Frank, from Arrighi to Wallerstein.

10 See the overview in my book: TAMÁS KRAUSZ, Reconstructing Lenin: An Intellectual Biography (New York: Monthly Review Press, 2015), 9-20.; for a critique of the post-1989 literature see also: LARS T. LIH, Lenin Rediscovered: What Is To Be Done? In Context. (Chicago: Haymarket Books, 2008) and Логинов, Владимир Ленин. Выбор пути: Биография.

11 See the review of PAUL LE BLANC, Lenin and his Biographers. See online: https://isreview. org/issue/86/lenin-and-his-biographers (Accessed June 19, 2019)

12 "It is obvious that Marx's basic idea that the development of the social-economic formations is a process of natural history cuts at the very root of this childish morality which lays claim to the title of sociology." V.I. LENIN, Collected Works (later see as: LCW) Vol. 1 (Moscow: Progress Publishers, 1964-1970), 136-141. 
of material" and the mere "description of phenomena" belong to the worst legacies of an outdated approach to science (even whilst Vladimir Ilyich Ulyanov himself was a meticulous researcher and seasoned analyst of sources).

The great Hungarian poet, Endre Ady wrote in 1909 about the intellectual climate at the time: "Everything Whole is now broken, every fire flickers in fragments," and how to restore this "whole" to the thinking about local and global "histories"? That was the question for Lenin.

The question closest to the heart of the new conception of sciencein Lenin's interpretation-was how the commodity system of the social economy develops, how it then develops into the capitalist machinery, and how Russian agriculture becomes subordinated to the capitalist local and global market system. Ulyanov outlined the basic concepts of the Marxian theory of social formations, modes of production, relations of production and property, etc., emphasizing the economic basis of social structure. ${ }^{13}$

Lenin regarded the social and economic differentiation of the peasantry, as directly associated with the spread of rural wage labor, as the greatest economic and social problem, from both a theoretical and specialized scientific perspective. It is in the course of his studies on the causes of peasant sub-differentiation that he arrives at his considerations with regard to the market and the question of the market economy: "The fundamental cause of the struggle of economic interests arising among the peasantry is the existence of a system under which the market is the regulator of social production." ${ }^{14} \mathrm{He}$ combined the problem of peasant differentiation and the formation of the market (economy) in his second important work: On the So-Called Market Question, published in $1893^{15}$

13 "The analysis of material social relations (i.e., of those that take shape without passing through man's consciousness: when exchanging products men enter into production relations without even realizing that there is a social relation of production here)-the analysis of material social relations at once made it possible to observe recurrence and regularity and to generalize the systems of the various countries in the single fundamental concept: social formation." Ibid., 140.

14 Ibid., 73.

15 Before writing this study, he presented it at a self-training debate (related to G. B. Krasin's lecture on The Market Question). Lenin expressed his views as a follow up to Krasin's lecture. Lenin wrote the study in the autumn of 1893, and it was first published in 1937. Н.Г. Голиков (ред.), Владимир Ильич Ленин. Биографическая хроника. Т. ІІ. (Москва: Политиздат, 1970), 80-1.; LCW, Vol. 1, 75-128. 
The first main sources of inspiration for Lenin apart from Marx and Engels, i.e., Plehanov and Kautsky, were also integrated in the development of his historical and political thought. Since his university years when he read Marx's Capital, Lenin's concept of history and his historical views had focused on three interrelated fundamental historical questions, which are difficult to separate. According to Radek as a witness, Marx's Capital "opened up a new world" for Lenin but "he had not yet found there answers to the specific Russian questions"16 to intellectually "solve" the problem of Russian capitalism and "the specificities of Russian historical development" as compared to Western development. ${ }^{17}$

This collision of modern and archaic features was reflected even in the famous discussion on the Asiatic mode of production in $1902^{18}$ of the first party program written by Plekhanov. Lenin had held its author responsible for the same striking Plekhanovian contradiction: "Plekhanov only spoke about capitalism in general terms", and left the question of a "specifically Russian form of capitalism" in the dark.19 As discussed earlier, these early methodological-theoretical differences between Lenin and Plekhanov were reflected in their assessment of the question of the Asiatic mode of production. Plekhanov did not relinquish his earlier position, which focused on the struggle of "Asianness" and "Europeanness" in Russian history, even fitting February and October 1917 into this scheme, an interpretation that finds followers even today. Unlike Lenin or later Trotsky, Plekhanov did not base his approach on a peculiar combination or accumulation of the two trends of historical development. In fact, the idea that the February Revolution fitted into the political "Europeanization" of Russia, whilst October reinstated the "Eastern," "Asiatic," or "peculiarly Russian," has once again become fashionable since the collapse of the Soviet Union. ${ }^{20}$

16 Логинов, Владимир Ленин. Выбор пути, 103.

17 The debate continues to the present. See: KRAUSz TAMÁs, Az orosz történelmi fejlödés ideológiáiról [On the Ideologies of the Russian Historical Development]. See online: http://www.c3.hu/scripta/scripta0/replika/1920/12krau.htm (Accessed June 19, 2019)

18 See Plekhanov's philosophical-historical fundamentals on Russia, in which he describes the characteristics of the swing between Western and Asian development, in his famous Introduction in Г.В. ПлЕХАНОВ, Сочинения в 24-х томах. Т. ХХ. (Москва: Гос. изд-во, 1925), $11-22$.

19 See on this the investigations of one of the outstanding figures of the first generation of Soviet party historians in the 1920s, in А.С. БуБнов, «Развития роли Ленина в истории русского марксизма» в Основные вопросы истории РКП: Сборник статей, А.С. БуБнов (Москва-Ленинград: Гос. изд-во, 1925) 113-133.

20 See: Krausz TAmÁs, Pártviták és történettudomány. Viták „az orosz történelmi fejlödés sajátosságairól", különös tekintettel az 1920-as évekre [Party Debates and History as 
Pavel Milyukov-the leading Russian liberal historian (belonging to the school of Klyuchevsky) at the end of 1870s-regarded first and foremost the British development to be a role of model for Russia. This concept entailed the possibility of a so-called catching-up development. Mikhail Pokrovsky, the leading Bolshevik historian ${ }^{21}$ conceived of the development of Russian and Western capitalism as identical since he located the "birth" of the capitalist system with the commercial capital of the $16^{\text {th }}$ century, and put the emphasis on global development instead of Russian specificity. This was the concept of the "agamogenesis of capitalism" in Russia, which is clearly reminiscent of similar debates today on the birth of global capitalism as inspired by Pomerantz. Lenin did not mix up the modern forms of capital with its antediluvian forms. In his approach the capitalist system is a market-based social system in which the capital relation, value-added production, the maximization of profit and the accumulation of capital are the dominant and complex social organisms, all on the basis of private ownership of capital and the capitalist state. ${ }^{22}$

It was clear to Lenin that the history of "modern society" should be interpreted as that of a global "world system" and the concrete framework of the capitalist mode of production. In his famous book, The Development of Capitalism in Russia, published in 1902, which is to be read as a truly historical analysis, he approached the specificities of Russian capitalism ${ }^{23}$

Science. Debates about the Specific Features of Russian Development Particularly Regarding the 1920s] (Budapest: Akadémiai Kiadó, 1991), 76-77.

The comparative analysis of the Lenin and Plekhanov's conceptual approach to revolution was completed by Tyutyukin [Тютюкин] in the Soviet period, taking Lenin's perspective on the unfolding events of course, but framed generally in objective analysis, in C.B. Тютюкин, Первая российская революция и Г. В. Плеханов. Из истории идейной борьбы в рабочем движении России в 1905-1907 г2. (Москва: Наука, 1981).

21 Pavel Milyukov (1859-1943) and the Bolshevik Pokrovsky (both were the disciples of Klyuchevsky at the University of Moscow, and later became famous historians) became the leading historians of liberals and of Bolsheviks.

22 Плимак, Политика переходной эпохи, 69-70. In relation to this subject he was studying Engels' "The Origin of the Family, Private Property and the State" at the same time, the spring of 1974. Seе: Голиков (ред.), Биографическая хроника. Т. І., 87. He accounted of this system, which he already interpreted as a world system at a young age, in a great variety of historical forms.

23 We speak of well-known Russian characteristics: a politically insignificant bourgeoisie, also economically at the mercy of the state bureaucratic autocracy, state-sponsored industrialization based on foreign capital, the dominance of the large estates and landed aristocracy, the role of the obshchina and the absence of peasant land and capital property in general, etc. 
from the perspective of the "suction effect"24 of modern Western societies as a relatively new historical phenomenon. ${ }^{25}$ Bolshevik historians (Pokrovsky, Olminsky)-opposed to Lenin-interpreted economic development exclusively on the basis of the Western European scheme. ${ }^{26}$

Meanwhile Lenin could not have known a number of rather important works by Marx, such as the Grundrisse, which was discovered by David Ryazanov-the director of the Marx-Engels Institute in Moscow working on the first edition of the collected works of Marx and Engels-only in 1923. The famous Introduction was found by Kautsky. ${ }^{27}$ Thus, it is a different question, to what extent he could-or he was able-to grasp the Marxian oeuvre in the strict academic sense of the word.

But for Lenin it was clear that without a creative adaptation of Marx's theory we have no means left to explain the globality of world history. Thus, long before the revolution he was engaged with the question of how the "modern center" of capitalism integrates and conquers other, "non-modern" parts of the world through this "suction effect". His solution lacked a lot of historical material we know now today after more than a century of scholarly discovery and development, but the important thing is that he posed the right question.

24 Since Lenin this suction effect has been a subject of several analyses but its most extensive and clear elaboration was manifest in the world-system theory, first and foremost, in the work of Immanuel Wallerstein.

25 LCW, Vol. 1, 12-3. Ulyanov "complemented" his investigations in economic history with approaches in general theory and political economy to place the nature and system of relation in peasant farming within the context of the flourishing system of capital as a whole, to capture the essence of capitalism conceptually.

26 Current mainstream literature in (economic) history reaches a conclusion not far removed from that of Lenin's, with regard to the basic structure of Russian capitalism, but does take a class-conscious view of armed revolutionary uprising, speaks not of "the conflict between the seat of power and society," but views it in terms of "the opposition between power and the extremist leftist social movements." See А.Н. Сахаров, «Введение. Россия В начале XX века: народ, власть, общество» [Introduction. Russia at the Beginning of the $20^{\text {th }}$ Century: People, Power, Society] в Россия в начале XX века, ред. А.Н. Яковлев (Москва: Новый Хронограф, 2002), 52-53.

The viewpoint of economic history is also shifting, as reflected in the final balance drawn under the pre-First World War decade of economic development drawn by Yu. A. Petrov [Ю.А. Петров] in the quoted book: “At the beginning of the twentieth century Russia remained a country with a backward economy by the standards of the developed nations, but entered the sphere of healthy economic growth within the framework of the market model." See: Ю.А. ПЕтРОв, «Российская экономика в начале XX в.» в Россия в начале XX века, 219.

27 See: MARCEllo Musto, Dissemination and Reception of the Grundrisse in the World. A Contribution to the History of Marxism. Manuscript, available online: https://www. marcellomusto.org/dissemination-and-reception-of-the-grundrisse-in-the-worldintroduction/317 (Accessed June 30, 2019) 
The image of Russia, which is located between East and West, has appeared in various interpretations by famous Russian historians (Klyuchevsky, Kovalevsky, etc.). In the case of Lenin this also meant a place "in between" the "developed" Western core countries-with modern terminology-and the Eastern colonies (China, India) and Turkey. Comparing its development with core countries Lenin elaborated two-coherenttheoretical inventions, which were developed in the course of this debate ${ }^{28}$ on the Russian development: (1) the problem of uneven development. (2) the hierarchical stratification of the capitalist world system, colonialism and its consequences, and the historical problem of the global accumulation of capital. ${ }^{29}$ These inventions can be regarded as very important insights into global history of key relevance today.

The insight that in the contemporary world of Lenin nearly all important contradictions of global development accumulated and concentrated in "one place," namely Russia, is inseparable from Lenin's historical analysis ${ }^{30}$ : for him, Russian history is global history. Even though Lenin overemphasized the development of capitalism in Russian agriculture, he did not subscribe to the misleading perspective of a significant group of Soviet historians in the 1920s, and then again in 1970s and 1980s, who "repeated" Pokrovsky's arguments about the specific features of Russian development. Other Soviet historians also referred to Lenin but they more convincingly stressed Russia's different economic development from the core countries, and they discussed the survival of feudal characteristics and the concept of various intersecting social formations in Lenin's theory. ${ }^{31}$ In other words: under capitalism as a global system the particular and the general forms of development are interconnected and they are determined by each other. ${ }^{32}$ Lenin's "neo-Marxism" thus in the longer run generated a radical shift in

28 See: Krausz, Pártviták és történettudomány, esp. 60-62.

29 Lenin proved already in his The Development of Capitalism in Russia that the Russian village community, the obshchina belongs to the historical past in spite of the fact that two decades earlier Marx had written a letter to Vera Zasulich, in which he argued that the obshchina had certain opportunities and a role in the future development of Russia.

30 Many historians emphasize this, from Christopher Hill to Hobsbawm and Plimak [Плимак].

31 On the history of these debates see: KRAUSz, Pártviták és történettudomány and Плимак, Политика переходной эпохи, 28-29.

32 "The development of capitalism certainly needs an extensive home market; but the ruin of the peasantry undermines this market, threatens to close it altogether and makes the organization of the capitalist order impossible. True, it is said that, by transforming the natural economy of our direct producers into a commodity economy, capitalism is creating a market for itself; but is it conceivable that the miserable remnants of the natural economy of indigent peasants can form the basis for the development in our country of the mighty capitalist production that we see in the West?" In LCW, Vol. 1, 79. 
how the development of Russia would and could be conceptualized as an integral part of world capitalism or "world history".

For Lenin the notions of "maturity" and "backwardness" became problematic only later, in his theory of imperialism. It was only after the experience of the World War I that he would revise his ideas and speak about modern capitalism as imperialism, the theory of which he summed up in five well-known theses.

The methodological shortcomings of Lenin's theoretical opponents at the time were rooted in their efforts to understand Russian development within the conceptual straitjacket of the structural forms of the Western model. Another problem is that the schematic "Westernizer's" concept of history has been unable to grasp the specificities of economic, labour and social history in Russian development and the great diversity of political, social, and class conflicts. ${ }^{33}$ To the present day Westernizers interpreted and interpret economic development exclusively on the basis of the Western European scheme. ${ }^{34}$ For instance, Yu. Petrov in his much quoted study published in 2002 claims: "At the beginning of the twentieth century Russia remained a country with a backward economy by the standards of the developed nations, but entered the sphere of healthy economic growth within the framework of the market model." ${ }^{35}$

\section{IMPERIALISM AS LOCAL AND GLOBAL HISTORY}

In Lenin's interpretation-quoting Arrighi-the "semi-peripheral integration" of Russia into the world market entailed an economic subordination to the Western great powers. Related developments can be explained through the

33 The "over-determination" of the social-political-economic contradictions within the Russian empire has a great literature in the contemporary and old Marxist historiography, from Perry Anderson to Emil Niederhauser, and we should also add the philosophers, who "specialized" in this topic: Lukács, Gramsci, Althusser, etc. On the history of these historiographical debates see: KRAUSz, Pártviták és történettudomány and Плимак, Политика переходной эпохи.

34 Seе: А.Н. Сахаров, «Введение. Россия в начале XX века: народ, власть, общество» в Россия в начале XX века, 52-53. See also: Ю.А. ПЕтРов, «Российская экономика в начале XX в.», в Россия в начале XX века, 219.

35 “Россия в начале XX в., по меркам развитых стран, оставалась страной с отсталой экономикой, но она вышла на траекторию здорового экономического роста в рамках рыночной модели.", Петров, «Российская экономика в начале XX в.», в Россия в начале ХХ века, 219. 
contemporary system of the international division of labor. In light of the experience of the Great War Lenin recognized that the role of the state had fundamentally increased in comparison with earlier development, indicating the beginning of a new era. As generally acknowledged, apart from Hobson, Hilferding had the biggest influence on Lenin's theory of imperialism, but it would be a mistake to overestimate their role. Lenin had already demonstrated-alongside Trotsky or Maslov-that the Tsar as the first, top capitalist entrepreneur, could participate-even in a subordinated position-in the struggle for the economic and geographical "division and re-distribution of the world". Russia-as Lenin himself interpreted it-was a relatively independent region, which had its own "modern center" and periphery. Lenin described the formation of this periphery as the "internal colonization" pursued by tsarism. ${ }^{36}$

In spite of its medieval-style imperial structure, Russia was a sub-imperial factor of the international economic and political struggles. ${ }^{37}$ The concept of sub-imperialism in itself was very important from the perspective of later analyses of the global economy and culture from an Eastern European perspective. It appears in the analysis of imperialism, and it continues to be very important in the debates of postcolonial critical literature, mainly in connection with Eastern European history.

In his work entitled Once More on the Theory of Realization, in 1899 Lenin captured the issue at stake as a matter of realization, conceiving of the problem of the market as a question of the world economy, the world system: "Do not stop-he claimed-at the traditional separation of the home and foreign markets when analyzing the question of capitalism. This distinction, groundless from a strictly theoretical point of view, is of particularly little use for such countries as Russia." 38

36 On this KRAUSz, Reconstructing Lenin.

37 See: GÖNCÖL GYÖRGY, "Rosa Luxemburg helye a marxizmus fejlödéstörténetében" [Rosa Luxemburg's Place in the History of the Evolution of Marxism], "Utószó" [Afterword] in RosA LUXEMBURG, A tőkefelhalmozás [The Accumulation of Capital] (Budapest: Kossuth Kiadó, 1979), 510-11.

38 GöncöL, "Rosa Luxemburg helye a marxizmus fejlődéstörténetében", “Utószó", Ibid.; and LCW, Vol. 4, 91. Göncöl gave an accurate account of the development of Lenin's views in other terms as well, when he pointed out that in Lenin's earlier quoted text on the "market question" he shared Adam Smith's thesis on the causal and linear connection between labor distribution and the market and explains capital's tendency for growth basically with technological advance alone, while in his later study ("Once More on the Theory of Realization") he writes about the "horizontal" and "vertical" tendencies involved in the spread of capitalism, as well as its universal and local bearings "in the creation of colonies, drawing wild tribes into the whirlpool of world capitalism." Ibid., 77-78. 
Lenin did come back to this question much later, underlining (in his book on imperialism) that imperialism itself was a new epoch of modern global history that incorporated the accumulation processes of previous historical epochs. He annotated and commented on Rosa Luxemburg's The Accumulation of Capital at extraordinary length in the year of its publication (it came out in January 1913), while living in Pornin. ${ }^{39}$ Luxemburg's accumulation theory posed the problem of the realization of surplus value in the new stage of the development of capitalism in an original way. Yet Lenin shifted the emphasis to the question of recapitalization of the realized surplus value, which would become the fundamental problem of the "period of imperialism" because this question was deeply intertwined with "the central issue of international exploitation in the world system of imperialism." ${ }^{40}$ Here Lenin and Luxemburg are in agreement in that the industrialization of the "backward countries and regions" itself subjugates, "colonizes" these territories through the "mediation" of loans. ${ }^{41}$ Lenin's main issue with Luxemburg's theory of capital accumulation was that in his opinion, as is widely known, there was no need for non-capitalist "sectors" and regions necessarily to be there for capital accumulation or realization of value to be possible.

Finally, Lenin came to correlate the factors of the world market-today it would be called globalization-and the demise of the Russian and Indian traditional forms of village community, making a reference, by way of example, to the cheap grain from the Northern American prairies and the Argentinean Pampas that flooded the market. The Indian and Russian peasant had proved powerless in the face of such competition, with the result

39 В.В. АДОРАТСКИЙ, Г.В. СОРИн (ред.), Ленинский сборник [Lenin miscellany] Т. XXII. (Москва: Партийное издательство, 1933), 343-390., translated for the Lenin Internet Archive (2010) by Steve Palmer. See online: http://www.marxists.org/archive/lenin/works/1913/apr/rlacc-capital-notes.htm (Accessed June 30, 2019) His chief issue with Luxemburg's theory of capital accumulation was that in his opinion, as widely known, there is no need necessarily for non-capitalist "sectors" and regions for there to be capital accumulation or realization of value.

40 GöncöL, "Rosa Luxemburg helye a marxizmus fejlődéstörténetében", 513.

41 The speed of falling in debt "in the case of backward regions surpasses the tempo of growth as a mathematical rule." See: GöncöL, "Rosa Luxemburg helye a marxizmus fejlődéstörténetében", Ibid.; and more current literature in Hungarian, BERNEK ÁGNES, FARKAS PÉTER (eds.), Globalizáció, tőkekoncentráció, térszerkezet [Globalization, capital concentration and structured space], (Budapest: MTA Világgazdasági Kutatóintézet, 2006); FARKAS PÉTER, A globalizáció és fenyegetései. A világgazdaság és a gazdaságelméletek zavarai [Globalization and its dangers. Disturbances in global economy and economic theory], (Budapest: Aula Kiadó, 2002). 
of "industrial-scale grain production" forcing patriarchal agriculture out of further vast tracts of land. ${ }^{42}$ One basic conclusion that could be drawn from Lenin's analysis was that overcoming the remains of patriarchal conditions of slavery itself manifests the expansion of capitalism. At the same time, while history forecloses any return to any traditional form of society, the more obstinate remnants of the forms that have become obsolete will often fuse with the modern system, as would be demonstrated later on by a vast number of eminent historians. The most modern capitalism entails the "colonial" and slave relations (not only in the peripheries), which penetrate several areas of both production and service..$^{43}$ These "pre-capitalist forms" were overlapping in the capitalist shell but the capitalist production and property relations as the "moment of overriding importance" (Lukács) determined the relations between the alternative "sectors" of social life as a whole.

Lenin in his book on imperialism ${ }^{44}$ demonstrated how in the process of generating extra-profit the hierarchized world system is reproduced, in close connection with "uneven and combined development”. Its internal mechanisms like the internationalization of global economic relations, financial control, labor migration etc. became new forms of exploitation. The relevance of this perspective will be demonstrated, I am sure, as we will

42 LCW, Vol. 3, 329.

43 For contemporary debates or the concept and theory of capitalism see: JÜRGEN KоскA, "A kapitalizmus fogalmának újrafelfedezése" [Rediscovering the Concept of Capitalism], Eszmélet, no. 113 (Spring 2017): 37-46. See online: https://epa.oszk. hu/01700/01739/00098/pdf/EPA01739_eszmelet_113_037-046.pdf (Accessed June 11, 2019); MARCEL VAN DER LINDEN, "Miért él tovább a kapitalizmus fogalma?" [Why Does the Concept of Capitalism Live On?], Eszmélet, no. 113 (Spring 2017): 47-59. See online: https://epa.oszk.hu/01700/01739/00098/pdf/EPA01739_eszmelet_113_047-059. pdf (Accessed June 11, 2019); SzIGETI PÉTER, “Kapitalizmusfogalmak és a tőkés termelési mód elmélete" [Notions of Capitalism. Theory of Capitalistic Mode of Production], Eszmélet, no. 115 (Autumn 2017), Melléklet [Supplement]. See online: http:/ /www.eszmelet.hu/wp-content/ uploads/2018/08/EPA01739_eszmelet_115_melleklet.pdf (Accessed June 11, 2019).

44 In the literature of history a fact that is often not properly considered is that in writing his pamphlet on imperialism Lenin brought an incredible force of scientific studies, statistical work to it. Only his notes and research "cards filled two whole volumes, which came to fill 400 and 500 pages respectively in print." See: Ленинский сборник T. [Vol.] XXII. (1933), and T. [Vol.] XXVII. (1934), 489. With the name index in volume in print alone coming to 470 items, whose majority comprises economists, historians, philosophers, sociologists, statisticians and of course, politicians. From Carnegie to Sombart, R. Hoeniger to E. Théry and J. Lescure to the Japanese Hishida, or J. Patouillet to Riesser the works of these annotated authors and the related data or commentary lines these sheets. See: LCW, Vol. 39. 
discuss the past and present of labor relation in quite a number of panels here at the conference.

Finance capital, Lenin argued "becomes very strong, [and] so does the state." In his introduction to Bukharin's analysis of imperialism in December 1915 Lenin remarked that the chain of mutual dependence and global inequalities is generated by a fundamental global hierarchy. ${ }^{45}$

At a later stage, it must be noted, Lenin and Rosa Luxemburg were perhaps the first amongst Marxists and non-Marxists to outline in a clear theoretical form that in the age of traditional, so to say "free" enterprisecapitalism the colonies had been drawn into commodity exchange but not into capitalist production. This changed in the age of imperialism. Imperialism is, among other things, the export of capital. Capitalist production was transplanted to the colonies at an ever-increasing rate. This colonial capitalist production extricated itself from dependence on European finance capital. These insights also are important today. From the military standpoint, as well as from the standpoint of expansion, tile separation of tile colonies is practicable, as a general rule, only "beyond capital"; under capitalism it is practicable only by way of exception or at the cost of a series of revolts and revolutions both in the colonies and the metropolitan countries. ${ }^{46}$

These investigations led Lenin to a discovery the significance of which simply cannot be overestimated. He summed up this discovery in the thesis of Russia as "the weak link in the chain of imperialism" and the "strong chain", i.e., the West as a stronghold of capitalism (Gramsci). ${ }^{47}$ This idea inferred the recognition that the chance for an anti-capitalist revolution to happen was present above all in the semi-periphery, and the imperialist butchery of World War I generated the historical chance for revolutionbecame an inevitable historical chance for mankind in order to get rid of this world order. Russia would only start the revolution that would take a social formation worldwide... This "story" is well known to all of us.

45 "Preface to N. Bukharin's Pamphlet Imperialism and the World Economy", LCW, Vol. 22, 240. See online: https://www.marxists.org/archive/bukharin/works/1917/imperial/intro.htm (Accessed June 28, 2019)

46 LCW, Vol. 22, 337-38.

47 For a historical background to this see: KRAUSz TAMÁs, A Szovjetunió története [The History of the Soviet Union], (Budapest: Kossuth Kiadó, 2008), I. fejezet: A „gyenge láncszem" - a cári önkényuralom bukása [Chapter 1. The Weak Link. The Fall of Tsarist Autocracy]. 


\section{EURO-CENTRISM AND CATCHING UP}

In Hungary, the sinologist and philosopher Ferenc Tőkei, and Georg Lukács ${ }^{48}$ were continuing the theoretical and methodological traditions outlined so far in the 1960s. Tökei rediscovered many writings and analyses of Marx and Lenin on Asia. Lukács in his Ontology describes Tőkei's reconstruction of the Marxian concept of the "Asiatic mode of production" as an important contribution to the Marxist theory of history.

So Lenin's thinking had the potential to generate a more differentiated anticolonialist way of thinking, since it questions the whole logic of the Eurocentric approach to old and modern global history.

In 1920, Lenin declared in his famous anti-colonialist document:

"With the aid of the proletariat of the advanced countries, the backward countries can pass over to the Soviet system and, through definite stages of development, to communism, without going through the capitalist stage. ... [We] ... should and will support bourgeois liberation movements in the colonies only when they are genuinely revolutionary, and when their exponents do not hinder our work of educating and organizing the peasantry and the broad mass of the exploited in a revolutionary spirit." ${ }^{\prime 9}$

In addition, very interesting in his remark on Russia before the revolution when he argued this way:

„But what of Russia? Its peculiarity lies precisely in the fact that the difference between "our" "colonies" and "our" oppressed nations is not clear, not concrete and not vitally felt! ... The sheer absurdity of trying to discover some serious difference between oppressed

48 Lukács described the work of Ferenc Tökei in the following terms: "Only one work has appeared recently on the Asiatic mode of production, which the Stalinist period wanted to eliminated from Marxism, to be replaced by a vacuous, artificial, so-called, 'Asiatic feudalism', unfortunately only in Hungarian, an excellent Marxist monograph by the sinologist Ferenc Tőkei, Az ázsiai termelési mód kérdéséhez [On the Issue of the Asiatic Mode of Production], (Budapest: Kossuth Kiadó, 1965)." It should be noted that Tökei's work appeared in a number of languages in later years.

49 See online: https://www.marxists.org/archive/lenin/works/1920/jul/x03.htm [On national and colonial question by Lenin], (Accessed June 28, 2019). 
nations and colonies in the case of Russia should be especially clear to a Russian socialist who wants not simply to repeat, but to think." ${ }^{20}$

The neoconservative currents of the 1980s have "swept out" of Eastern Europe all "great theories" including first and foremost the theory of social formations alongside the old state-legitimizing ideologies. Systemic changes in Eastern Europe and in the Soviet Union, have restored the old "order". Marxism was delegitimized exactly at the time when the question of property and property relations became a fundamental historical issue in Eastern European everyday life in the course of privatization and the transfer of property as the concrete realization of the "primitive accumulation of capital." The mainstream liberal and nationalist historiographies of the changes of regimes in Eastern Europe produced whole ideologies in order to prove that the new political system would follow a project of "catching-up style development" and the realization of bourgeois democracy, and the region would soon catch up with Western Europe. Jürgen Habermas was just one of those who got lost "between three pine trees" as a Russian proverb says. At the time the typical narrative explained the events of ' 89 as a "rectifying revolution"-this is Habermas's term-which carries the people back from an illusion to the world of the western type of democracy, as if our societies had been at the gates of a new stage of development in order to catch up with the West. ${ }^{51}$

Yet the anti-capitalist traditions of thinking on global history from Eastern Europe described in this presentation enabled a group of historians even in a small country like Hungary, and some of their colleagues in other Eastern European countries to predict already in the early 1990s that the restorative changes of regimes of 1989-91 would not lead to the celebrated catching-up style development. ${ }^{52}$ In a large part of the Eastern European region, including Poland and Hungary, "catching-up" and the whole project

50 LCW, Vol. 23. 55-56.

51 See also: JÜRGEN HABERMAS, “What Does Socialism Mean Today? The Rectifying Revolution and the Need for New Thinking on the Left", New Left Review, 1/183 (September-October 1990).

52 Already at the beginning of the 1990s we can document a left-wing critique of "catchingup style development" and the theories, which explained the "backwardness" of Eastern Europe through the idea of socialism. See: SuSAN ZIMMERMAnN, "Delinking and Catching up in East and West", Links, no. 3, 1994.; and NIEDERHAUSER EMIL, "Előhang 1989 KeletEurópájához" [Foreword to the Eastern Europe of 1989], Eszmélet, no. 5 (Spring 1990): 24-42. See online: http://www.eszmelet.hu/niederhauser_emil-elohang-1989-kelet-europajahoz/ (Accessed June 28, 2019). 
of western bourgeois democracy was doomed to failure from the very beginning. We argued early in the 1990s that the new, oligarchic capitalism can only function through the help of an authoritarian regime in line with the Eastern European-Russian traditions in national cloth-even under Western European and later on European Union patronage. ${ }^{53}$

In the Russia of 1917, and again in 1991, the social and economic preconditions for a bourgeois democratic transformation had been similarly lacking, and no such regime would be established in the quarter of a century that has passed since 1991. It was evident for us even in 1989 that it is impossible to build a bourgeois democracy since a democratic bourgeoisie cannot be built from above, by the state. After 1989 we have seen "transitology", so-called modernization theory, the various concepts of totalitarianism ${ }^{54}$, and more recently the increasing prevalence of a lukewarm resistance to large-scale critical social theory of global capitalism, or to just any theory, as the characteristic modes of thinking about Eastern Europe in global history. All of these modes of knowledge production simply implicate several old and new characteristics of subordination and oppression of Eastern Europe and in Eastern Europe. By contrast, if they just incorporated critically and constructively extant Eastern European traditions of thinking on global history, historians would not and could not be surprised at the formation of authoritarian regimes within the region. The intellectual "return" of these present day Eastern European regimes themselves to a historical thinking that directly builds on the nationalist and racist theories of history of the interwar era is not accidental either.

53 See also: Krausz TAMÁs, Megélt rendszerváltás [The Change of Regimes as I experienced It], (Budapest: Cégér Könyvkiadó, 1994)

54 On the „Promotion” of Totalitarianism in the Anglo-Saxon Sovietology see:SHEILA FITZPATRICK, "Revisionism in Soviet History", History and Theory 46, 4 (2007): 77-91. DOI: 10.1111/j.14682303.2007.00429.x; VIOLA LYNNE, "The Cold War in American Soviet Historiography and the End of the Soviet Union", The Russian Review 61, 1 (2002): 25-34. DOI: 10.1111/1467-9434.00203 For a critical discussion of totalitarianism see also: SHEILA FITZPATRICK, MICHAEL GEYER (eds.), Beyond Totalitarianism: Stalinism and Nazism Compared (New York: Cambridge University Press, 2009). See also: KRAUSz TAMÁs, "A GULAG aktualitása" [The Actuality of the Gulag], in GULAG. A szovjet táborrendszer története [Gulag - History of the Soviet Network of ForcedLabour Camps], eds. Krausz TAmÁs, BARTHA EszTer (Budapest: Pannonica Kiadó, 2001), 13-26.; BARTHA ESZTER, “A sztálinizmus a régi és új historiográfiában: A jelenség meghatározásának elméleti és módszertani problémái" [Stalinism in the Old and New Historiography: The Theoretical and Methodological Problems of Defining the Phenomenon], in A sztálinizmus hétköznapjai. Tanulmányok és dokumentumok a sztálinizmus történetéböl [The Everyday Life of Stalinism. Essays and Documents from the History of Stalinism], ed. KRAUSz TAMÁS (Budapest: Nemzeti Tankönyvkiadó, 2003), 15-39. 
By contrast, at the beginning of the $20^{\text {th }}$ century, critical historiography could not imagine "catching-up" on a capitalist basis. Lenin repeatedly underlined the plundering and parasitic character of modern capitalist accumulation. "The epoch of imperialism", he wrote, "is an epoch in which the world is divided among the great privileged nations which oppress all the others"; and it went without saying for a Marxist theoretician such as Lenin that the local ruling classes and privileged groups of the peripheries were also interested in the maintenance of this world order. None of these great problems of capitalism in its semi-peripheral regions has been solved during the past 100 years, all the great economic and social changes which have characterized this past century notwithstanding. I think a historian who deals with global history cannot avoid these questions. Historical research that is reluctant to recognize this fact, lacks moral credibility, which is or should be an essential part of an academia that serves the public. 